\title{
RAPID COASTAL ADAPTATION ASSESSMENT AT CITY OF ANNAPOLIS
}

\author{
Don M. Bain, P.E., SumSmart, don.bain@sumsmart.com \\ Stacey Underwood, P.E., U.S. Army Corps of Engineers, stacey.m.underwood@usace.army.mil \\ Thomas Laczo, P.E., U.S. Army Corps of Engineers, thomas.d.laczo@usace.army.mil \\ Michael J. Dowling, Michael J. Dowling Architects, mdowlingra@gmail.com \\ David Kriebel, PhD., P.E., U.S. Naval Academy, kriebel@usna.edu
}

\section{SUMMARY APPROACH}

Alerted to the increased flood risks posed by sea level rise and potential storm surge riding in on a rising sea, the City of Annapolis is eager to better understand the extent of its coastline at risk, adaptation alternatives and typical costs previously experienced when such alternatives are applied.

A rapid assessment method is developed and applied to characterize the coastline, survey the coastline for current and potential adaptation measures and develop a portfolio of potential actions with representative costs.

A rapid assessment team is assembled consisting of private sector engineers and architects, an engineering professor from the U.S. Naval Academy and engineers from the U.S. Army Corps of Engineers.

This paper reports on the method, activities and results to better inform stakeholders of increasing coastal flood risk and potential investment requirements for adaptation.

\section{RISK}

The City of Annapolis experiences increasing tidal flooding and accelerating sea level rise. Two hurricanes in the last hundred years flooded the city with storm surges 5.6 feet above mean sea level.

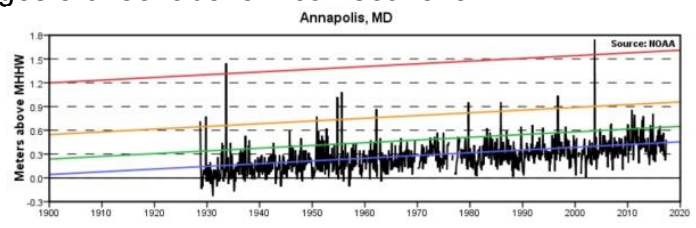

Figure 1 - Annapolis Extreme Water Levels (NOAA)

City planning follows NOAA guidance for local sea level rise scenarios as advised in Sweet [2017] and uses the scenario data localized to the tide metering station at Annapolis. The NOAA 1.0 and 2.5 sea level rise scenarios from Sweet [2017] combined with $1 \%$ annual flood levels or 5.6 feet historical storm surge are used to project future potential flood levels for evaluating future risk.

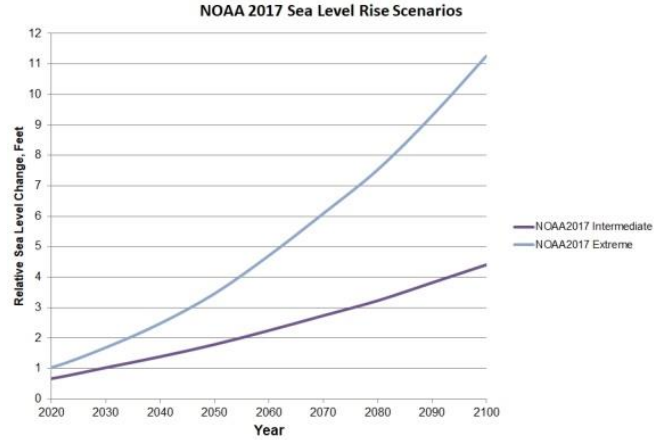

Figure 2 - NOAA 2017 Intermediate and Extreme SLR Scenarios for Annapolis

\section{ASSESSING THE SHORELINE}

The Annapolis coastline is described using a simple taxonomy: natural gentle, natural steep, bulkhead, stone revetment, sand and marsh. A review of topographic maps is used for preliminary determination of shoreline slope and coastline segments at greater relative risk. Satellite images are used to develop a preliminary indication of how specific shoreline segments fit to the taxonomy. Shoreline designations are indicated in draft form on maps used in the next step.

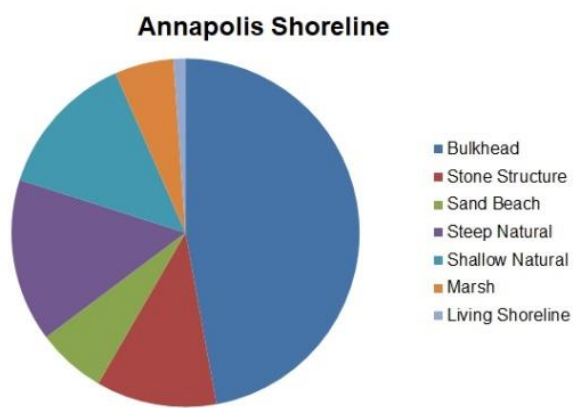

Figure 3 - Characterization of shoreline

Equipped with maps and preliminary shoreline designations, the team takes to a boat provided by the City of Annapolis Harbormaster to inspect the shore. Maps with shoreline designations are updated based on observations. Critical infrastructure including bridges and a wastewater treatment plant are inspected.

\section{ADAPTATION ALTERNATIVES}

Stakeholders including public officials, private property owners and taxpayers are interested in the adaptation alternatives available and their costs.

The team gathers practical adaptation alternatives including levees, seawalls, bulkheads, stone sills with natural systems (living shorelines). Elevating roadways, parking lots and existing seawalls are considered. Dry and wet-floodproofing are appropriate adaptation alternatives for structures and are developed as part of 
an activity separate from this assessment.

While the selection of adaptation alternative for each shoreline type is ultimately up to owners in the case of private properties and public officials in the case of public properties, a preliminary match between shoreline and adaptation alternative is sufficient for rough analysis

\section{COST MODELS}

Each adaptation alternative requires investment. Specific costs for an adaptation solution at a specific shoreline require a proper engineering feasibility study. Feasibility studies require significant funds and time, typically months, to prepare. Stakeholders have need of rough cost indicators for use in quickly iterating on and screening adaptation ideas, prior to committing to feasibility study.

Pro forma costs derived from projects in the U.S. Army Corps of Engineers' database that roughly match each adaptation alternative are useful for rough, back-of-theenvelope cost estimates and analysis. A cost model for each adaptation alternative is developed using parameters that scale cost with a dimension appropriate to the application. In the case of bulkheads for example, once baseline parameters are established (e.g. height 4 feet higher than mean high water with 12 inch diameter anchor piles 20 feet in length at 6 -foot spacing), cost estimates are expressed per linear foot of bulkhead. $\$ 1,460$ per linear foot of timber bulkhead informs stakeholders of potential future investment requirements for a city with over 50,000 feet or about 9.5 miles of existing bulkhead that will require eventual replacement and relocation.

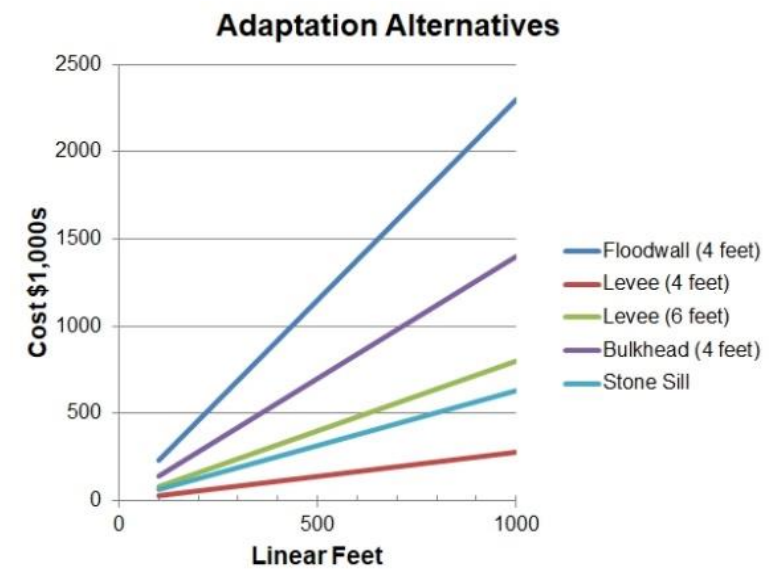

Figure 4 - Simple cost models for adaptation alternatives at the water's edge

Parametric cost models for raising streets (per linear foot) and raising parking and pedestrian areas (per square yard) are also developed. Annapolis-specific adaptation actions including raising the new seawall at City Dock and extending the seawall with new T-wall are developed.

Each adaptation alternative cost model is supported by a fact sheet that presents assumptions, advantages and disadvantages. Conveying those qualifiers and stressing the eventual need for subsequent feasibility studies are major priorities when engaging with stakeholders.

\section{SUMMARY}

Characterizing the Annapolis shoreline provides context for discussing adaptation alternatives to which stakeholders relate. Desktop review of maps and satellite images followed by field verification is quick and inexpensive. Adaptation alternative fact sheets with simple, rough cost models that scale with the application are powerful tools for focusing stakeholders on adaptation choices and decisions.

These combine to enable the essential benefits of allowing stakeholders to work together to:

- $\quad$ address increased flood risk through scenarios

- explore adaptation alternatives and their tradeoffs

- $\quad$ develop rough estimates of future investment requirements

- $\quad$ develop draft governance processes for addressing increased coastal flood risk and adaptation decision-making.

\section{REFERENCE}

Sweet, Kopp, Weaver, Obeysekera, Horton, Thieler, Zervas [2017]: Global and Regional Sea Level Rise Scenarios for the United States, NOAA Technical Report NOS CO-OPS 083. 